Article

\title{
Presence of Babesia odocoilei and Borrelia burgdorferi Sensu Stricto in a Tick and Dual Parasitism of Amblyomma inornatum and Ixodes scapularis on a Bird in Canada
}

\author{
John D. Scott ${ }^{1, *}$, Kerry L. Clark ${ }^{2}$ and Lance A. Durden ${ }^{3}$ \\ 1 International Lyme and Associated Diseases Society, 2 Wisconsin Circle, Suite 700, \\ Chevy Chase, MD 20185-7007, USA \\ 2 Environmental Epidemiology Research Laboratory, Department of Public Health, University of North \\ Florida, Jacksonville, FL 32224, USA; kclark@unf.edu \\ 3 Department of Biology, Georgia Southern University, Statesboro, GA 30458, USA; \\ ldurden@georgiasouthern.edu \\ * Correspondence: jkscott@bserv.com; Tel.: +1-519-843-3646
}

Received: 11 February 2019; Accepted: 13 March 2019; Published: 20 March 2019

check for updates

\begin{abstract}
Wild birds transport ticks into Canada that harbor a diversity of zoonotic pathogens. However, medical practitioners often question how these zoonotic pathogens are present in their locality. In this study, we provide the first report of an Amblyomma inornatum tick cofeeding with a blacklegged tick, Ixodes scapularis, which parasitized a Veery, Catharus fuscescens-a neotropical songbird. Using the flagellin (flaB) gene of the Lyme disease bacterium, Borrelia burgdorferi sensu lato, and the 18S rRNA gene of the Babesia piroplasm, a malaria-like microorganism, we detected Borrelia burgdorferi sensu stricto and Babesia odocoilei, respectively, in an I. scapularis nymph. After the molt, these ticks can bite humans. Furthermore, this is the first documentation of B. odocoilei in a tick parasitizing a bird. Our findings substantiate the fact that migratory songbirds transport neotropical ticks long distances, and import them into Canada during northward spring migration. Health care practitioners need to be aware that migratory songbirds transport pathogen-laden ticks into Canada annually, and pose an unforeseen health risk to Canadians.
\end{abstract}

Keywords: Borrelia burgdorferi sensu stricto; Lyme disease; Babesia; babesiosis; $18 \mathrm{~S}$ rRNA gene; ticks; birds; ectoparasite; tick-borne pathogens

\section{Introduction}

Ticks have medical and veterinary importance because they are vectors of multiple zoonotic microorganisms [1]. Hard-bodied ticks (Acari: Ixodidae) often harbor a wide array of bacterial, piroplasmic, and viral microorganisms, and transmit them to vertebrate hosts [1-3]. Wild birds provide long-distance dispersal of ixodid ticks, whereas terrestrial vertebrates facilitate short-distance movement. In the temperate zone of North America, Lyme disease and human babesiosis are the most frequent tick-borne diseases [4].

Lyme disease is a zoonotic disease caused by members of the Borrelia burgdorferi sensu lato (Bbsl) complex, and is generally transmitted to humans by blood-feeding ticks [5]. Worldwide, there are at least 23 genospecies in this complex, and B. burgdorferi sensu stricto is one of the genospecies that is pathogenic to humans. Not only do Ixodes species transmit Bbsl, certain Amblyomma and Rhipicephalus ticks have been reported to transmit Bbsl in east-central South America [6]. Morphologically, Bbsl is pleomorphic; it has diverse forms (i.e., spirochetes, blebs, 
round bodies, and granules) and, jointly, can form biofilms [7]. This spirochetal zoonosis has been associated with numerous dermatologic, neurologic, rheumatologic, cardiac, ophthalmological, otologic, gastrointestinal, endocrine, and psychiatric manifestations [8]. Only $14-41 \%$ of Lyme disease patients recall a tick bite [4,9], and $9-39 \%$ have an erythema migrans (EM) rash $[4,10,11] ;>50 \%$ have a homogeneous rash [10]. In nature, Bbsl is transmitted transstadially (larva to nymph to adult) in competent vector ticks, such as blacklegged ticks, Ixodes scapularis [1].

Human babesiosis is a zoonosis caused by members of the genus Babesia. These malaria-like microorganisms, which are piroplasms (Apicomplexa: Piroplasmida: Babesiidae), are typically transmitted by ixodid ticks to vertebrates, including humans. These apicomplexan parasites are highly adaptive in apposite ticks and suitable hosts. In I. scapularis, Babesia piroplasms are transmitted by transovarial transmission (female to eggs) [12] and by transstadial passage [13]. When a Babesia-infected tick starts to feed on a warm-blooded host, it transmits sporozoites from its salivary glands to the blood stream of its host, and sporozoites quickly invade erythrocytes. Patients may initially be asymptomatic, later have acute and fulminating symptoms that may culminate in death, especially if the patients are elderly ( $>55$ years), splenectomized, immunocompromised, or coinfected with another tick-borne pathogen $[13,14]$.

Songbirds (Passeriformes), in particular, can transport ticks hundreds of kilometers into Canada during northward spring migration [15-22]. Long-distance, passerine migrants can transport bird-feeding ticks from as far south as Brazil, and widely disperse them across Canada [20-22]. Whenever a songbird is parasitized by two or more tick species, which are infected with one or more pathogens, this avian host can become parasitemic and act as a reservoir of these tick-borne pathogens.

In recent tick-host-pathogen studies, $15 \%$ to $59 \%$ of I. scapularis nymphs collected from songbirds in southern Canada were infected with Bbsl [17,20-22]. Additionally, immature stages of Amblyomma species, including A. americanum, A. dissimile, A. humerale, A. imitator, A. inornatum, A. longirostre, A. maculatum, A. rotundatum, and $A$. sabanarae, are imported into Canada by southern temperate and neotropical songbirds [23-25]. Passerine migrants have the potential to import a bevy of ticks and their associated tick-borne pathogens from the Neotropics. Zoogeographically, A. inornatum is primarily found in the southernmost Nearctic region, but also in the northern Neotropical region. The known natural range of $A$. inornatum extends from southern Texas to Panama [26,27]. This narrow landmass is a major flyway for migratory birds during bi-directional migration. In Canada, $A$. inornatum ticks were previously reported [17]; however, the background and descriptions for those ticks were incomplete.

Amblyomma inornatum parasitizes a wide range of vertebrate hosts including Bovidae (e.g., sheep, goats, cattle), Cervidae (e.g., deer, elk), Dasypodidae (e.g., armadillo), Tayassuidae (e.g., peccary), Cricetidae (e.g., hispid cotton rats), Sciuridae (e.g., ground squirrels), Leporidae (e.g., rabbits, hares), Equidae (e.g., horses), Didelphidae (e.g., opossum), Felidae (e.g., cats), and Canidae (e.g., coyotes, dogs) [26-30]. This Amblyomma tick also parasitizes Galliformes (e.g., pheasants) and Passeriformes (perching birds, such as Veeries). From a medical standpoint, Medlin et al. state that $A$. inornatum bites humans [30].

The antiquity and origin of ticks and their associated pathogens is often questioned. Ancient ticks fossilized in amber have existed in the Western Hemisphere for more than 99 million years [31]. Some of these prehistoric ticks fed on feathered dinosaurs and certain ancient birds. Based on a fossilized tick from the Dominican Republic amber mines, Babesia piroplasms originated 30-45 Ma (million years ago) [32], while Borrelia bacteria date back 15-20 Ma [33]. Not only have the descendants of these ixodid ticks and associated microorganisms survived dramatic climate shifts, they have adapted to multiple arthropod-vertebrate interactions.

Historically, on mainland Ontario, Banerjee et al. documented the first PCR-positive Bbsl isolate cultured from a blacklegged tick that was collected from an untraveled dog residing at Kenora [34]. Up to $56 \%$ of Lyme disease patients in the northeastern U.S.A. are concomitantly infected with Babesia piroplasms [35]. The intensity and profusion of symptoms in patients with simultaneous occurrence of Lyme disease and human babesiosis is normally greater than in patients with either disease alone [36]. 
The aim of this study was to determine whether passerines are continuing to transport extralimital ticks to Canada and to ascertain whether they are harboring any zoonotic pathogens that have not been identified previously.

\section{Materials and Methods}

\subsection{Tick Collection}

Ticks were collected from a neotropical songbird by bird banders using fine-pointed, stainless steel forceps. Live ticks were put in a transparent, round-bottom, $8.5 \mathrm{~mL}$ polypropylene tube (15.7 mm $\times 75 \mathrm{~mm}$, round based) (Sarstedt, Montréal, Québec, Canada). The mouth of the tube was covered with tulle netting (3-cm diameter) to allow ventilation for ticks. A polyethylene push cap with a 7-mm hole was placed into the mouth of the tube to secure the tulle netting, and prevent ticks escaping. Each tube, which contained the ticks from one host, was placed in a double-zipped plastic bag with a slightly moistened paper towel to maintain high humidity. All ticks were sent to the lab for identification (J.D.S.). The Amblyomma nymph was tentatively identified using a taxonomic key [27] and, following the nymph-adult molt, Amblyomma taxonomic keys for adults indigenous in the Western Hemisphere were used [28,37]. Similarly, for Ixodes nymphs, a nymphal taxonomic key was used [38]. Ixodes species were exposed to a long-day photoperiod of 16:8 h (Light:Dark), while Amblyomma ticks from the Neotropics were held at a photoperiod of 12:12 h (L:D). Complete records (i.e., geographic location, tick collection date, tick species, developmental life stage, and host species) were logged for each tick collection. To preserve ticks, they were stored in 2-mL microtubes containing 95\% ethyl alcohol. The Amblyomma sp. female, 18-5A70B, was compared to specimens in the U.S. National Tick Collection.

\subsection{Bacteria and Piroplasm Detection}

Ticks were tested using a nested PCR that amplifies a portion of the flagellin (flaB) gene of Bbsl, with slight variations from a previously described protocol [39]. The primary PCR assay, which targets a 497-nt fragment of the flaB gene, used the following primers, 271F: 5'-AAG-GAA-TTG-GCA-GTT-CAA-TCA-GG-3' and 767R: 5'-GCA-TTT-TCT-ATT-TTA-GCAAGT-GAT-G-3'. The secondary (nested) PCR amplified a 437-nt internal fragment using primers, 301F: 5'-ACA-TAT-TCA-GAT-GCA-GAC-AGA-GG-3' ${ }^{\prime}$ and 737R: 5'-GCA-TCA-ACT-GTA-GTT-GTA-ACATTA-ACA-GG-3'.

For Babesia testing and DNA sequencing of ticks, the same protocol was used as previously described by Casati et al. [40]. DNA sequencing of amplicons of the $18 \mathrm{~S}$ ribosomal RNA (18S rRNA) of the genus Babesia was employed to delineate species. Of note, the $18 \mathrm{~S}$ rRNA gene is a highly conserved gene.

\subsection{DNA Sequence Analysis}

PCR products from the Babesia 18S rRNA and the Borrelia flaB positive samples were purified using the Wizard ${ }^{\circledR S V}$ Gel and PCR Clean-Up System (Promega, Madison, WI, USA). DNA templates were sequenced [41] using both the forward and reverse primers used in the nested PCRs. Investigator-derived sequences were compared with those obtained by searching the GenBank database (National Center for Biotechnology Information) using the Basic Local Alignment Search Tool (BLAST) [42], and aligned using Clustal X [43].

Nucleotide sequence accession numbers: The DNA nucleotide sequences for the Babesia $18 \mathrm{~S}$ and Bbsl flaB gene fragments obtained from ticks in this study were deposited in the GenBank database with accession numbers MK628544 and MK620851, respectively. 


\subsection{Molecular Tick Identification}

The methodology used for the molecular identification of the Amblyomma sp. female, 18-5A70B, was carried out at the Centre of Biodiversity Genomics (CBG), University of Guelph. The algorithm was previously described [44].

\section{Results}

\subsection{Identification of Amblyomma Tick}

An Amblomma sp. nymph was collected from a Veery, Catharus fuscescens, on 16 May, 2018, at the Ruthven Park National Historic Site Banding Station, Haldimand Bird Observatory, Cayuga, Ontario: $42.97 \mathrm{~N}, 79.87 \mathrm{~W}$. Using a photoperiod of 12:12 h (L:D), this fully engorged Amblyomma nymph molted to a female in $37 \mathrm{~d}$. The newly formed female was allowed to become fully sclerotized before it was morphologically identified. The author (J.D.S.) provided preliminary identification, and the co-author (L.A.D.) provided verification of the identification. Taxonomic keys for adult Amblyomma species in the Neotropics were also employed to confirm the identification of this tick species [28,37]. This female specimen was also compared with confirmed A. inornatum females in the U.S. National Tick Collection, matched favorably with them, and the species was confirmed as A. inornatum.

\subsection{Identification of Tick-Borne Pathogens}

Based on DNA sequence analysis, B. burgdorferi sensu stricto for Bbsl, and B. odocoilei were detected in the I. scapularis nymph.

\subsection{Molecular Tick Assessment}

Molecular analysis of the Amblyomma specimen (18-5A70B) was undertaken, but we were unable to amplify a valid barcode sequence for this tick specimen.

\section{Discussion}

We provide the first report of A. inornatum (nymph) and an I. scapularis (nymph) cofeeding on a bird in Canada. Even though these two tick species have individually been documented on passerines, this is the first-ever account of coinfestation on a bird anywhere. This discovery is congruent with previous bird-tick studies which show that migratory songbirds transport Amblyomma ticks from neotropical areas into Canada. Specifically, the I. scapularis nymph was coinfected with Bbsl and B. odocoilei. Ultimately, these tick-borne, zoonotic pathogens may be a serious health risk to humans.

\subsection{Identification of Amblyomma inornatum}

The coinfestation of I. scapularis and A. inornatum on a bird in Canada is a first. Even though Ogden et al. reported A. inornatum on wild birds in Canada, they did not provide details, such as background information, a morphological description, or confirmation of identification [17]. Since there are at least 57 Amblyomma spp. In the neotropical region, including the Caribbean sub-region, identifying larvae and nymphs morphologically makes for unreliable identifications [45]. Taxonomic keys are not available to delineate all of these immature species. When these larval and nymphal Amblyomma ticks are collected from spring migratory songbirds in Canada, there is a strong possibility for misidentification because they are outside their established geographical distribution. Moreover, the account of an A. inornatum male on a bird in the Ogden et al. study is questionable because adults are not known to parasite passerines.

Within a tick-conducive microenvironment, replete nymphs (i.e., I. scapularis, A. inornatum) will molt to adults, and start questing for suitable vertebrate hosts, including humans. A photograph of an I. scapularis female parasitizing a human shows that ticks often take a blood meal in concealed locations on the body (Figure 1). 


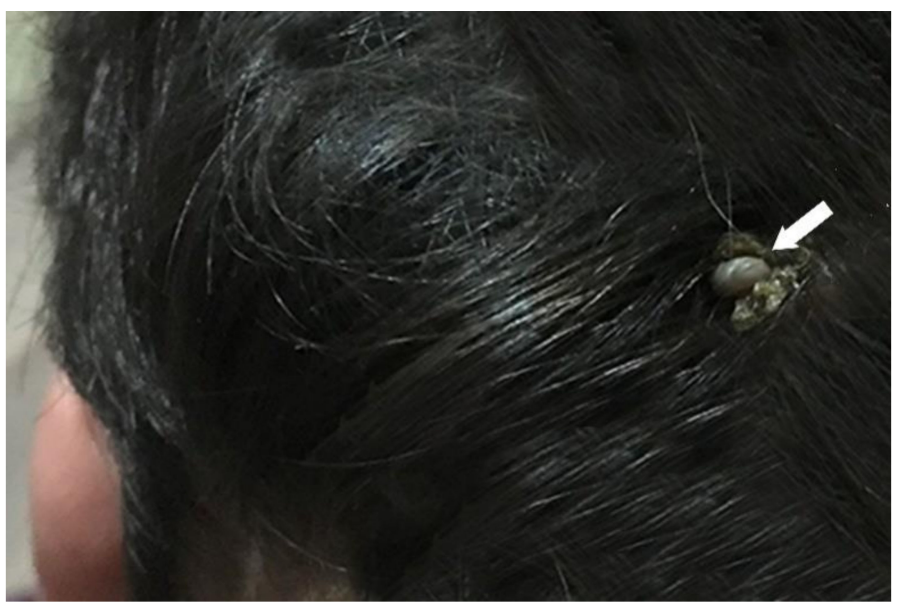

Figure 1. Blacklegged tick, Ixodes scapularis, partially engorged female parasitizing a 7-year-old boy. This female was attached on the nape of the neck where it had been feeding for 4 days. If this tick was infected with tick-borne pathogens, it could have easily transmitted tick-borne pathogens to the boy. Exudates formed around the tick when it was disturbed by hair brushing. If this female had become fully engorged, and was not found and removed, it could have caused tick paralysis (if it was genetically predisposed to synthesize paralysis biotoxins).

In order to confirm the identification of $A$. inornatum in the present study, we allowed the fully engorged nymph to molt to an adult (female). After the nymph-adult molt, the Amblyomma female was keyed to A. inornatum using two Amblyomma keys for adults [28,37]. Morphologically, the distinguishing characteristics include: 1) Coxa I with an external spur that is much longer than the internal spur and 2) scutum inornate. The specimen matched favorably with confirmed A. inornatum females in the U.S. National Tick Collection. We provide confirmatory evidence of A. inornatum in Canada.

\subsection{Flight Path of Veery}

Veeries start their northward migratory flight from their wintering grounds in central and southeastern South America. From there, they head northward to breeding grounds in north-central and northeastern U.S.A. These night-time fliers may use transoceanic pathways or employ overland routes through Central America [46]. Veeries can fly up to $285 \mathrm{~km} /$ night [47]. At this flight pace, a Veery could fly from the Mexico-U.S. border to Ruthven Park, Ontario, a distance of $2600 \mathrm{~km}$, in $9 \mathrm{~d}$. The Veery has a low percentage of body fat and, thus, must stop periodically along the flight path to replenish its energy reserves [47]. This timeline indicates that the A. inornatum nymph is a slow feeder during migratory flight. Moreover, a fully engorged tick normally drops from its host when the peripheral sensory organs deduce a suitable microhabitat [1]. Since A. inornatum is native to Central America, Mexico, and southern Texas, the Veery must have followed the Mississippi Flyway northward and proceeded through the Ohio River valley to Ruthven Park, Ontario.

In their indigenous distribution, A. inornatum nymphs have peak questing activity from February through May [30]. This host-seeking activity period corresponds with the northbound migration of Veeries en route through Central America. Likewise, the host-seeking activity period of I. scapularis nymphal ticks in the upper Midwest overlaps peak migration of Veeries [48]. Since the I. scapularis nymph was partially engorged, it most likely parasitized the Veery in the Ohio River valley. Both the fully engorged A. inornatum and the partially engorged I. scapularis were collected from the host bird at Ruthven Park in mid-May during peak spring migration, which coincides with the peak questing period of nymphs for both A. inornatum and I. scapularis. 


\subsection{Sequence of Zoonotic Infection During Flight of Veery}

The presence of Bbsl and B. odocoilei in the I. scapularis nymph, but not in the A. inornatum nymph, indicates that the Veery was likely not infected with these two pathogens. Based on the flight pace of the Veery and the extent of engorgement of the I. scapularis nymph, it is most likely that the host bird was parasitized in the Ohio valley two days before arrival and banding at Ruthven Park. The I. scapularis nymph possibly acquired Bbsl and B. odocoilei while taking a blood meal as a larva. More studies are needed to determine what vertebrate hosts simultaneously harbor both Bbsl and B. odocoilei. Even though A. inornatum is a non-indigenous tick in Canada, nymphs have ample time to molt during late spring and early summer to either males or females. Subsequently, both A. inornatum and I. scapularis females have adequate time to molt and transmit these tick-borne zoonotic microbes to humans.

In its native area, A. inornatum is known to harbor several tick-borne pathogens. For instance, Medlin et al. detected the following tick-borne pathogens in A. inornatum ticks collected in southern Texas: (1) endosymbiotic spotted fever group rickettsial species, Rickettsia amblyommatis (previously "Candidatus Rickettsia amblyommii"), (2) Candidatus Borrelia lonestari (a possible causative agent of southern tick rash-like illness), (3) Ehrlichia chaffeensis (causative agent of human monocytic ehrlichiosis), and (4) Bbsl [30].

When a pathogen-laden tick is cofeeding on a songbird with other ticks, it can transmit pathogens to these attached ticks. As soon as the host bird becomes parasitemic, it can systematically transmit pathogens to engorging ticks. For instance, Babesia sporozoites are stored in the tick salivary glands, and transmitted once the tick starts to take a blood meal from its host [12]. Endogenous transmission of sporozoites promptly occurs during the initial stage of engorgement. Not only can an infected bird be a reservoir, it can be an enzootic bridge for tick-borne pathogens. Whenever songbird-transported ticks are infected with one or more of these pathogens, they can subsequently induce acute illness in unsuspecting patients.

\subsection{Tick-Host-Pathogen Dynamics}

Cervids play an important role in the enzootic transmission cycle of B. odocoilei. The isolation of B. odocoilei from the blood of white-tailed deer, Odocoileus virginianus, was first achieved in Texas, and reveals that this cervid is a reservoir host $[49,50]$. Biogeographically, this piroplasm overlaps with the distribution of I. scapularis [50]. White-tailed deer are hosts of all three motile stages (larvae, nymphs, adults) of I. scapularis, and support the reproduction of this hematophagous ectoparasite. Ecologically, both white-tailed deer and I. scapularis perpetuate the enzootic transmission cycle of B. odocoilei. Transovarial and transstadial transmission of B. odocoilei occur in I. scapularis and, upon tick feeding, Babesia sporozoites are promptly transmitted, and entry ensues and multiplication takes place within the erythrocytes of cervid hosts [50]. Whenever larval or nymphal I. scapularis parasitize a white-tail deer, and become infected with B. odocoilei, they molt to the next life stage and can subsequently transmit sporozoites to vertebrate hosts, including humans. Paradoxically, Bbsl and Babesia odocoilei have different enzootic transmission pathways with cervid hosts. White-tailed deer are refractory to Bbsl, whereas cervids are reservoir-competent hosts of B. odocoilei $[49,50]$.

With regard to avian hosts, Anderson and Magnarelli isolated Bbsl from the blood of passerine birds (i.e., Gray Catbird, Common Yellowthroat and American Robin) [51]. Pointedly, Anderson et al. isolated Bbsl from the liver of a Veery and, likewise, from I. scapularis larvae collected from Veeries [52]. In addition, McLean et al. cultured Bbsl from the blood of a Song Sparrow, Melospiza melodia, in the upper Midwest [53]. In the southeastern U.S.A., Durden et al. documented Bbsl in skin biopsies removed from passerine birds, and revealed that songbirds act as disseminators of Lyme disease spirochetes [54]. Richter et al. used spirochete-free xenodiagnostic I. scapularis larvae to show that the American Robin, Turdus migratorius, is a reservoir-competent host of Bbsl [55]. Since there is essentially no transovarial transmission of Bbsl in I. scapularis females [56], the I. scapularis nymph must have acquired Lyme disease spirochetes directly from the host Veery or indirectly when the nymph was feeding as a larva on a Bbsl-infected, reservoir-competent host. Pathologically, 
I. scapularis is known to carry and transmit at least 10 different tick-borne, zoonotic pathogens [1]. Upon repletion, some individual, fully engorged I. scapularis females can cause tick paralysis if they are not removed promptly.

In Europe, Babesia microti has been detected in Ixodes ricinus larvae feeding on European Robins, Erithacus rubecula [57]. In addition, Babesia divergens has been detected in bird-feeding I. ricinus, which is a competent vector of several tick-borne pathogens. In North America, Hersh et al. revealed that certain passerines (i.e., Wood Thrushes, Veeries, Gray Catbirds, American Robins) are reservoir competent hosts for B. microti [58]. They also documented a triple infection (i.e., B. microti, Bbsl, and Anaplasma phagocytophilum) in an I. scapularis nymph collected from a Veery. Based on our findings, and those of other researchers, Veeries play a significant role in the enzootic transmission dynamics of Bbsl and certain Babesia species.

Although there is uncertainty at this point in time, B. odocoilei may possibly be pathogenic to humans. This piroplasm is in the same sister group, namely the Babesia sensu stricto clade (i.e., EU1, a European genotype; Babesia divergens; Babesia divergens-like species) that is pathogenic to humans $[59,60]$. The EU1 strains are most closely related to $B$. odocoilei, but they differ significantly over the entire $18 \mathrm{~S}$ rRNA gene from B. odocoilei. When Babesia serology is conducted, B. odocoilei may be cross-reacting with more familiar Babesia spp. (i.e., Babesia microti, Babesia duncani). More studies are needed to culture B. odocoilei from patients and to juxtapose them with Babesia serology.

\subsection{Impact of Babesia and Borrelia burgdorferi Infections on Humans}

Globally, there are over 100 recognized species of Babesia and, in North America, they infect a wide range of avian and mammalian hosts, including humans [61]. These apicomplexan piroplasms are pleomorphic, and have four diverse forms (i.e., gametes, sporozoites, merozoites, and trophozoites) [12]. When Babesia-infected ticks feed on vertebrates, sporozoites are transmitted from the tick's salivary glands without delay, and invade the hosts' red blood cells. Not only is this intraerythocytic parasite transmitted by ticks, it can be transmitted by blood transfusion [62] and transplacental transmission $[63,64]$. Common symptoms include fatigue, chills, sweats, headache, muscle aches, listlessness, dullness, nausea, and sleep disturbance. Cases of babesiosis can present with a high parasite burden, severe pathology, and fatal outcomes. Human babesiosis infections may recrudesce and persist and, ultimately, the resulting parasitemia can cause a fulminating, life-threatening zoonosis. Due to non-specific symptoms and possible coinfection with other tick-borne pathogens, human babesiosis is often misdiagnosed and underreported [65]. Although there are Babesia case reports in Canada, only one nationwide study of $B$. duncani has been published in the scientific literature [66].

The underdetection of Lyme disease and associated tick-borne diseases is a major pitfall across Canada [67]. The most frequently occurring clinical manifestations include neuro-associated symptoms $(84 \%)$, fatigue (62\%), and musculoskeletal-associated symptomology (57\%) [4]. As a stealth pathogen, Bbsl slips by host defenses and sequesters in deep-seated tissue (i.e., ligaments, tendons, bone, eye, brain, muscle, glial and neuronal cells, synovium, and scar tissue) [68-79]. The persistence of Bbsl in chronic Lyme disease patients is well documented $[4,80,81]$. In the advanced stage, patients can have cognitive impairment that results in a gradually developing spectrum of neuropsychiatric symptoms $[82,83]$. When Lyme disease is not treated, or inadequately treated, chronic Lyme disease can result in fatal outcomes [72,84]. Transplacental transmission of Bbsl in humans has been documented with adverse fetal outcomes, including physiological dysfunction and musculoskeletal deformities [85-89].

Based on the MyLymeData, an online patient registry for chronic Lyme disease, $44 \%$ of the respondents had Babesia as the most common coinfection [4]. This study also revealed that psychiatric disorders (52\%) were the most common misdiagnosis [4]. Concurrent Lyme disease and human babesiosis is typically more grave than either zoonosis by itself $[35,90]$. The co-occurrence of Lyme disease and human babesiosis typically makes clinical symptoms more severe, intense, and long-lasting [90,91]. Bbsl weakens the immune system, and makes these co-occurring infections more difficult to treat. 


\section{Conclusions}

We provide the first report of $B$. odocoilei in a tick parasitizing a bird. The presence of B. odocoilei and Bbsl in a bird-feeding I. scapularis nymph indicates that this vector tick may subsequently transmit a dual infection to a suitable host, including a human. The cofeeding of A. inornatum and I. scapularis ticks on a Veery is significant because it is the first-ever account of these two tick species simultaneously parasitizing a bird. This bird parasitism also reveals that neotropical songbirds can transport ticks long distances and introduce foreign pathogenic microbes from the Neotropics, Mexico, and the United States, and widely disperse them across Canada during northward spring migration. Since migratory songbirds transport multiple ticks and associated zoonotic pathogens from southern latitudes into Canada, health care practitioners must watch for, and fervently treat these tick-borne zoonoses with due diligence.

Author Contributions: J.D.S. was responsible for study design and coordinating this tick-host project. K.L.C. conducted molecular testing of ticks and analysis of PCR amplicons. L.A.D. confirmed the identification of ticks. All authors read and approved the final manuscript.

Funding: Funding was provided in part by the Mary Alice Holmes Memorial Foundation.

Acknowledgments: We thank Nikki Coble and Taylor Ballantyne for technical assistance. We also thank Derek Ludkin for collecting ticks from the Veery. We appreciate clerical and technical support from Catherine Scott. We thank Monica Young for sharing her expertise on barcoding analysis. We are grateful to Amanda Green for computer graphics.

Conflicts of Interest: The authors declare no conflicts of interest.

\section{References}

1. Nicholson, W.A.; Sonenshine, D.E.; Noden, B.H. Ticks (Ixodida). In Medical and Veterinary Entomology, 3rd ed.; Mullen, G.R., Durden, L.A., Eds.; Academic Press/Elsevier: London, UK, 2019; pp. 603-672. ISBN 978.

2. Reed, K.D.; Meece, J.K.; Henkel, J.S.; Shukla, S.K. Birds, migration and emerging zoonoses: West Nile virus, Lyme disease, influenza A and enteropathogens. Clin. Med. Res. 2003, 1, 5-12. [CrossRef]

3. Goodman, J.L.; Dennis, D.T.; Sonenshine, D.E. Tick-Borne Diseases of Humans; ASM Press: Washington, DC, USA, 2005; p. 401. ISBN 9781555812386.

4. Johnson, L.; Shapiro, M.; Mankoff, J. Removing the mask of average treatment effects in chronic Lyme disease research using Big Data and subgroup analysis. Healthcare 2018, 6, 124. [CrossRef] [PubMed]

5. Burgdorfer, W.; Barbour, A.G.; Hayes, S.F.; Benach, J.L.; Grunwaldt, E.; Davis, J.P. Lyme disease-A tick-borne spirochetosis? Science 1982, 216, 1317-1319. [CrossRef]

6. Miziara, C.S.M.G.; Serrano, V.A.G.; Yoshinari, N. Passage of Borrelia burgdorferi through diverse ixodid hard ticks caused distinct diseases: Lyme borreliosis and Baggio-Yoshinari syndrome. Clinics 2018, 73, e394. [CrossRef] [PubMed]

7. Meriläinen, L.; Herranen, A.; Schwarzbach, A.; Gilbert, L. Morphological and biochemical features of Borrelia burgdorferi pleomorphic forms. Microbiology 2015, 161, 516-527. [CrossRef] [PubMed]

8. Stricker, R.B.; Fesler, M.C. Chronic Lyme disease: A working case definition. Am. J. Infect. Dis. 2018, 14, 44. [CrossRef]

9. Berger, B.W. Dermatologic manifestation of Lyme disease. Rev. Infect. Dis. 1989, 11 (Suppl. 6), S1475-S1481. [CrossRef]

10. Stonehouse, A.; Studdiford, J.S.; Henry, A. An update on the diagnosis and treatment of early Lyme disease: "focusing on the bull's-eye, you may miss the mark". J. Emerg. Med. 2010, 39, e147-e151. [CrossRef]

11. Johnson, L.; Mankoff, J.; Stricker, R.B. Severity of chronic Lyme disease compared to other chronic conditions: A quality of life survey. PeerJ 2014, 2, e322. [CrossRef]

12. Mehlhorn, H.; Shein, E. The piroplasms: Life cycle and sexual stages. Adv. Parasitol. 1984, 23, 37-103.

13. Kjemtrup, A.M.; Conrad, P.A. Human babesiosis: An emerging tick-borne disease. Austral. Soc. Parasitol. 2000, 30, 1323-1337. [CrossRef]

14. Homer, M.J.; Aguilar-Delfin, I.; Telford, S.R., III; Krause, P.J.; Persing, D.H. Babesiosis. Clin. Microbiol. Rev. 2000, 13, 451-469. [CrossRef] 
15. Scott, J.D.; Fernando, K.; Banerjee, S.N.; Durden, L.A.; Byrne, S.K.; Banerjee, M.; Mann, R.B.; Morshed, M.G. Birds disperse ixodid (Acari: Ixodidae) and Borrelia burgdorferi-infected ticks in Canada. J. Med. Entomol. 2001, 38, 493-500. [CrossRef] [PubMed]

16. Morshed, M.G.; Scott, J.D.; Fernando, K.; Beati, L.; Mazerolle, D.F.; Geddes, G.; Durden, L.A. Migratory songbirds disperse ticks across Canada, and first isolation of the Lyme disease spirochete, Borrelia burgdorferi, from the avian tick, Ixodes auritulus. J. Parasitol. 2005, 91, 780-790. [CrossRef] [PubMed]

17. Ogden, N.H.; Lindsay, L.R.; Hanincová, K.; Barker, I.K.; Bigras-Poulin, M.; Charron, D.F.; Heagy, A.; Francis, C.M.; O'Callaghan, C.J.; Schwartz, I.; et al. Role of migratory birds in introduction and range expansion of I. scapularis ticks and of Borrelia burgdorferi and Anaplasma phagocytophilum in Canada. Appl. Environ. Microbiol. 2008, 74, 1780-1790. [CrossRef] [PubMed]

18. Scott, J.D.; Lee, M.-K.; Fernando, K.; Durden, L.A.; Jorgensen, D.R.; Mak, S.; Morshed, M.G. Detection of Lyme disease spirochete, Borrelia burgdorferi sensu lato, including three novel genotypes in ticks (Acari: Ixodidae) collected from songbirds (Passeriformes) across Canada. J. Vector Ecol. 2010, 35, 124-139. [PubMed]

19. Scott, J.D.; Anderson, J.F.; Durden, L.A. Widespread dispersal of Borrelia burgdorferi-infected ticks collected from songbirds across Canada. J. Parasitol. 2012, 98, 49-59. [CrossRef]

20. Scott, J.D.; Durden, L.A. New records of the Lyme disease bacterium in ticks collected from songbirds in central and eastern Canada. Int. J. Acarol. 2015, 41, 241-249. [CrossRef]

21. Scott, J.D.; Clark, K.L.; Foley, J.E.; Bierman, B.C.; Durden, L.A. Far-reaching dispersal of Borrelia burgdorferi sensu lato-infected blacklegged ticks by migratory songbirds in Canada. Healthcare 2018, 6, 89. [CrossRef] [PubMed]

22. Scott, J.D.; Clark, K.L.; Foley, J.E.; Anderson, J.F.; Bierman, B.C.; Durden, L.A. Extensive distribution of the Lyme disease bacterium, Borrelia burgdorferi sensu lato, in multiple tick species parasitizing avian and mammalian hosts across Canada. Healthcare 2018, 6, 131. [CrossRef]

23. Scott, J.D.; Durden, L.A. Amblyomma dissimile Koch (Acari: Ixodidae) parasitizes bird captured in Canada. Syst. Appl. Acarol. 2015, 20, 854-860. [CrossRef]

24. Scott, J.D.; Durden, L.A. First record of Amblyomma rotundatum tick (Acari: Ixodidae) parasitizing a bird collected in Canada. Syst. Appl. Acarol. 2015, 20, 155-161. [CrossRef]

25. Scott, J.D. Birds widely disperse pathogen-infected ticks. In Seabirds and Songbirds: Habitat Preferences, Conservation, Migratory Behavior; Mahala, G., Ed.; Nova Publishers, Inc.: New York, NY, USA, 2015; pp. 1-22. ISBN 978.

26. Guglielmone, A.A.; Estrada-Peña, A.; Keirans, J.E.; Robbins, R.G. Ticks (Acari: Ixodida) of the Neotropical Zoogeographic Region; International Consortium on Ticks and Tick-borne Diseases: Atalanta, GA, USA; Houten, the Netherlands, 2003; p. 173. ISBN 987.

27. Keirans, J.E.; Durden, L.A. Illustrated key to nymphs of the tick genus Amblyomma (Acari: Ixodidae) found in the United States. J. Med. Entomol. 1998, 35, 489-495. [CrossRef] [PubMed]

28. Guzmán-Cornejo, C.; Robbins, R.G.; Guglielmone, A.A.; Montiel-Parra, G.; Pérez, M. The Amblyomma (Acari: Ixodida: Ixodidae) of Mexico: Identification keys, distribution and hosts. Zootaxa 2011, 2998, 16-38.

29. Guglielmone, A.A.; Robbins, R.G.; Apanaskevich, D.A.; Petnery, T.N.; Estrada-Pena, A.; Horak, I.G. The Hard Ticks of the World (Acari: Ixodidae); Springer: Dordrecht, the Netherlands, 2014; ISBN 978.

30. Medlin, J.S.; Cohen, J.I.; Beck, D.L. Vector potential and population dynamics for Amblyomma inornatum. Ticks Tick Borne Dis. 2015, 6, 463-472. [CrossRef]

31. Peñalver, E.; Arillo, A.; Delclòs, X.; Peris, D.; Grimaldi, D.A.; Anderson, S.R.; Nascimbene, P.C.; Pérez-de la Fuente, R. Ticks parasitised feathered dinosaurs as revealed by Cretaceous ambler assemblages. Nature Commun. 2018, 8, 1924. [CrossRef] [PubMed]

32. Poinar, G., Jr. Fossilized mammalian erythrocytes associated with a tick reveal ancient piroplasms. J. Med. Entomol. 2017, 54, 895-900. [CrossRef]

33. Poinar, G., Jr. Spirochete-like cells in a Dominican amber Amblyomma tick (Arachnida: Ixodidae). Hist. Biol. 2015, 27, 565-570. [CrossRef]

34. Banerjee, S.N.; Christensen, C.I.; Scott, J.D. Isolation of Borrelia burgdorferi on mainland Ontario. Can. Com. Dis. Rep. 1995, 21, 85-86.

35. Benach, J.L.; Coleman, J.L.; Habicht, G.S.; MacDonald, A.; Grunwaldt, E.; Giron, J.A. Serological evidence for simultaneous occurrences of Lyme disease and babesiosis. J. Infect. Dis. 1985, 152, 473-477. [CrossRef] 
36. Curcio, S.R.; Tria, L.P.; Gucwa, A.L. Seroprevalence of Babesia microti in individuals with Lyme disease. Vector Borne Zoonotic Dis. 2016, 16, 737-743. [CrossRef]

37. Jones, E.K.; Clifford, C.M.; Kohls, G.M. The ticks of Venezuela (Acarina: Ixodoidea) with a key to the species of Amblyomma in the Western Hemisphere; Brigham Young University Science Bulletin, Biological Series, No. 4; Brigham Young University: Provo, UT, USA, 1972; Volume 17, p. 40.

38. Durden, L.A.; Keirans, J.E. Nymphs of the Genus Ixodes (Acari: Ixodidae) of the United States: Taxonomy, Identification Key, Distribution, Hosts, and Medical/Veterinary Importance. Monographs; Thomas Say Publications in Entomology, Entomological Society of America: Lanham, MD, USA, 1996; p. 95.

39. Clark, K.; Hendricks, A.; Burge, D. Molecular identification and analysis of Borrelia burgdorferi sensu lato in lizards in the southeastern United States. Appl. Environ. Microbiol. 2005, 71, 2616-2625. [CrossRef]

40. Casati, S.; Sager, H.; Gern, L.; Piffaretti, J.-C. Presence of potentially pathogenic Babesia sp. for human in Ixodes ricinus in Switzerland. Ann. Agric. Environ. Med. 2016, 13, 65-70.

41. McCombie, W.R.; Heiner, C.; Kelly, J.M.; Fitzgerald, M.G.; Gocayne, J.D. Rapid and reliable fluorescent cycle sequencing of double stranded templates. DNA Seq. 1992, 2, 289-296. [CrossRef]

42. Altschul, S.F.; Gish, W.; Miller, W.; Myers, E.W.; Lipman, D.J. Basic local alignment search tools. J. Mol. Biol. 1990, 215, 403-410. [CrossRef]

43. Thompson, J.D.; Gibson, T.J.; Plewniak, F.; Jeanmougin, F.; Higgins, D.G. The ClustalX-Windows interface: Flexible strategies for multiple sequence alignment aided by quality analysis tools. Nucleic Acids Res. 1997, 25, 4876-4882. [CrossRef]

44. Scott, J.D.; Durden, L.A. First report of a blacklegged tick, Ixodes scapularis Say (Acari: Ixodidae), parasitizing a raptor in Canada. Syst. Appl. Acarol. 2015, 22, 208-216. [CrossRef]

45. Guglielmone, A.A.; Robbins, R.G. Hard Ticks (Acari: Ixodida: Ixodidae) Parasitizing Humans, 1st ed.; Springer: New York, NY, USA, 2018; p. 314. ISBN 9783319955520.

46. eBird Primary Reference. Available online: https://help.ebird.org/customer/en/portal/articles/1006835-recommended--citation (accessed on 16 March 2019).

47. The Virtual Nature Trail at Penn State New Kensington Species Pages. 16 March. Available online: https: //www.psu.edu/dept/nkbiology/naturetrail/speciespages/veery.html (accessed on 16 March 2019).

48. Mannelli, A.; Kitron, U.; Jones, C.J.; Slajchert, T.L. Influence of season and habitat on Ixodes scapularis infestation on white-footed mice in northwestern Illinois. J. Parasitol. 1994, 80, 1038-1043. [CrossRef]

49. Holman, P.J.; Waldrup, K.A.; Wagner, G.G. In vitro cultivation of a Babesia isolated from a white-tailed deer (Odocoileus virginianus). J. Parasitol. 1988, 74, 111-115. [CrossRef]

50. Holman, P.J.; Madeley, J.; Craig, T.M.; Allsopp, B.A.; Allsopp, M.T.; Petrini, K.R.; Waghela, S.D.; Wagner, G.G. Antigenic, phenotypic and molecular characterization confirms Babesia odocoilei isolated from three cervids. J. Wildl. Dis. 2000, 36, 518-530. [CrossRef]

51. Anderson, J.F.; Magnarelli, L.A. Avian and mammalian hosts for spirochete-infected ticks and insects in a Lyme disease focus in Connecticut. Yale J. Biol. Med. 1984, 57, 627-641.

52. Anderson, J.F.; Johnson, R.C.; Magnarelli, L.A.; Hyde, F.W. Involvement of birds in the epidemiology of Lyme disease agent Borrelia burgdorferi. Infect. Immun. 1986, 51, 394-396.

53. McLean, R.G.; Ubico, S.R.; Norton Hughes, C.A.; Engstrom, S.M.; Johnson, R.C. Isolation and characterization of Borrelia burdorferi from blood of a bird captured in the Saint Croix River Valley. J. Clin. Microbiol. 1993, 31, 2038-2043.

54. Durden, L.A.; Oliver, J.H., Jr.; Kinsey, A.A. Ticks (Acari: Ixodidae) and spirochetes (Spirochaetaceae: Spirochaetales) recovered from birds on a Georgia barrier island. J. Med. Entomol. 2001, 38, 231-236. [CrossRef]

55. Richter, D.; Spielman, A.; Komar, N.; Matuschka, F.-R. Competence of American Robins as reservoir hosts for Lyme disease spirochetes. Emerg. Infect. Dis. 2000, 6, 133-138. [CrossRef]

56. Rollend, L.; Fish, D.; Childs, J.E. Transovarial transmission of Borrelia spirochetes by Ixodes scapularis: A summary of the literature and recent observations. Ticks Tick Borne Dis. 2013, 4, 46-51. [CrossRef]

57. Hildebrandt, A.; Franke, J.; Meier, F.; Sachse, S.; Dorn, W.; Straube, E. The potential role of migratory birds in transmission cycles of Babesia spp., Anaplasma phagocytophilum, and Rickettsia spp. Ticks Tick Borne Dis. 2010, 1, 105-107. [CrossRef]

58. Hersh, M.H.; Osfeld, R.S.; McHenry, D.J.; Tibbetts, M.; Brunner, J.L.; Killilea, M.E.; LoGiudice, K.; Schmidt, K.A.; Keesing, F. Co-infestation of blacklegged ticks with Babesia microti and Borrelia burgdorferi is higher than expected and acquired from small mammal hosts. PLoS ONE 2014, 9, e99348. [CrossRef] 
59. Herwaldt, B.L.; de Bruyn, G.; Pieniazek, N.J.; Homer, M.; Lofy, K.H.; Siiemenda, S.B.; Fritsche, T.R.; Persing, D.H.; Limaye, A.P. Babesia divergens-like infection, Washington State. Emerg. Infect. Dis. 2004, 10, 622-629. [CrossRef]

60. Gorenflot, A.; Moubri, K.; Percigout, E.; Carey, B.; Schetters, T.P. Human babesiois. Ann. Trop. Med. Parasitol. 1998, 92, 489-501. [CrossRef]

61. Shock, B.C.; Moncayo, A.; Cohen, S.; Mitchell, E.A.; Williamson, P.C.; Lopez, G.; Garrison, L.E.; Yabsley, M.J. Diversity of piroplasms detected in blood-fed and questing ticks from several states in the United States. Ticks Tick Borne Dis. 2014, 5, 373-380. [CrossRef]

62. Villatoro, T.; Karp, J.K. Transfusion-transmitted babesiosis. Arch. Pathol. Lab. Med. 2019, 143, $130-134$. [CrossRef]

63. Cornett, J.K.; Malhotra, A.; Hart, D. Vertical transmission of babesiosis from a pregnant, splenectomized mother to her neonate. Infect. Dis. Clin. Pract. 2012, 20, 408-410. [CrossRef]

64. Fox, L.M.; Winger, S.; Ahmed, A.; Arnold, A.; Chou, J.; Rhein, L.; Levy, O. Neonatal babesiosis: Case report and review of the literature. Pediatr. Infect. Dis. J. 2006, 25, 169-173. [CrossRef]

65. Sherr, V.T. Human babesiosis-An unrecorded reality: Absence of formal registry undermines it detection, diagnosis and treatment, suggesting need for immediate mandatory reporting. Med. Hypotheses 2005, 63, 609-615. [CrossRef]

66. Scott, J.D.; Scott, C.M. Human babesiosis caused by Babesia duncani has widespread distribution across Canada. Healthcare 2018, 6, 49. [CrossRef]

67. Lloyd, V.K.; Hawkins, R.G. Under-detection of Lyme disease in Canada. Healthcare 2018, 6, 125. [CrossRef]

68. Häupl, T.; Hahn, G.; Rittig, M.; Krause, A.; Schoerner, C.; Schönherr, U.; Kalden, J.R.; Burmester, G.R. Persistence of Borrelia burgdorferi in ligamentous tissue from a patient with chronic Lyme borreliosis. Arthritis Rheum. 1993, 36, 1621-1626. [CrossRef]

69. Müller, M.E. Damage of collagen and elastic fibres by Borrelia burgdorferi-Known and new clinical histopathogical aspects. Open Neurol. J. 2012, 6 (Suppl. 1), S179-S186.

70. Oksi, J.; Mertsola, J.; Reunanen, M. Subacute multiple-site osteomyelitis cause by Borrelia burgdorferi. Clin. Infect. Dis. 1994, 19, 891-896. [CrossRef]

71. Preac-Mursic, V.; Pfister, H.W.; Spiegel, H.; Burk, R.; Wilske, B.; Reinhardt, S. First isolation of Borrelia burgdorferi from an iris biopsy. J. Clin. Neuroophthalmol. 1993, 13, 155-161.

72. Oksi, J.; Kalimo, H.; Marttila, R.J.; Marjamäki, M.; Sonninen, P.; Nikoskelainen, J.; Viljanen, M.K. Inflammatory brain changes in Lyme borreliosis: A report on three patients and review of literature. Brain 1996, 119, 2143-2154. [CrossRef]

73. MacDonald, A.B. Alzheimer's neuroborreliosis with trans-synaptic spread of infection and neurofibrillary tangles derived from intraneuronal spirochetes. Med. Hypotheses 2007, 68, 822-825. [CrossRef]

74. Miklossy, J. Alzheimer's disease-A neurospirochetosis. Analysis of the evidence following Koch's and Hill's criteria. J. Neuroinflamm. 2011, 8, 90. [CrossRef]

75. Frey, M.; Jaulhac, B.; Piemont, Y.; Marcellin, L.; Boohs, P.M.; Vautravers, P.; Jesel, M.; Kuntz, J.L.; Monteil, H.; Sibilia, J. Detection of Borrelia burgdorferi DNA in muscle of patients with chronic myalgia related to Lyme disease. Am. J. Med. 1998, 104, 591-594. [CrossRef]

76. Ramesh, G.; Borda, J.T.; Dufour, J.; Kaushal, D.; Ramamoorthy, R.; Lackner, A.A.; Philipp, M.T. Interaction of the Lyme disease spirochete Borrelia burgdorferi with brain parenchyma elicits inflammatory mediators from glial cells as well as glial and neuronal apoptosis. Am. J. Pathol. 2008, 173, 1415-1427. [CrossRef]

77. Ramesh, G.; Santana-Gould, L.; Inglis, F.M.; England, J.D.; Philipp, M.T. The Lyme disease spirochete Borrelia burgdorferi induces inflammation and apoptosis in cells from dorsal root ganglia. J. Neuroinflamm. 2013, 10, 88. [CrossRef]

78. Girschick, H.J.; Huppertz, H.I.; Rüssmann, H.; Krenn, V.; Karch, H. Intracellular persistence of Borrelia burgdorferi in human synovial cells. Rheumatol. Int. 1996, 16, 125-132. [CrossRef]

79. Klempner, M.S.; Noring, R.; Rogers, R.A. Invasion of human skin fibroblasts by the Lyme disease spirochete, Borrelia burgdorferi. J. Infect. Dis. 1993, 167, 1074-1081. [CrossRef]

80. Middelveen, M.J.; Burke, J.; Sapi, E.; Bandoski, C.; Filush, K.R.; Wang, Y.; Franco, A.; Timmaraju, A.; Schlinger, H.A.; Mayne, P.J.; et al. Culture and identification of Borrelia spirochetes in human vaginal and seminal secretions. F1000Research 2015, 3, 309. [CrossRef]

81. Embers, M.E.; Hasenkampf, N.R.; Jacobs, M.B.; Tardo, A.C.; Doyle-Meyers, A.; Philipp, M.T.; Hodzic, E. Variable manifestations, diverse seroreactivity and post-treatment persistence in non-human primates exposed to Borrelia burgdorferi by tick feeding. PLoS ONE 2017, 12, e0189071. [CrossRef] 
82. Bransfield, R.C. Suicide and Lyme and associated diseases. Neuropsychiatr. Dis. Treat. 2017, 13, $1575-1587$. [CrossRef]

83. Bransfield, R.C. Aggressiveness, violence, homocidality, homicide, and Lyme disease. Neuropsychiatr. Dis. Treat. 2018, 14, 693-713. [CrossRef]

84. Liegner, K.B.; Duray, P.; Agricola, M.; Rosenkilde, C.; Yannuzzi, L.A.; Ziska, M.; Tilton, R.C.; Hulinska, D.; Hubbard, J.; Fallon, B.A. Lyme disease and the clinical spectrum of antibiotic responsive chronic meningoencephalomyelitides. J. Spir. Tick Borne Dis. 1997, 4, 61-73.

85. Feder, H. Borrelia infections: Lyme disease. In Remington and Klein's Infectious Diseases of the Fetus and Newborn Infant, 8th ed.; Wilson, C.B., Nizet, V., Maldonado, Y., Remington, J.S., Klein, J.O., Eds.; Elsevier: Philadelphia, PA, USA, 2016; pp. 544-557. ISBN 9780321472.

86. Lavoie, P.E.; Lattner, B.P.; Duray, P.H.; Malawista, A.G.; Barbour, R.C. Culture positive, seronegative, transplacental Lyme borreliosis infant mortality. In Proceedings of the IV International Conference on Lyme Borreliosis, Stockholm, Sweden, 18-21 June 1990.

87. MacDonald, A.B. Gestational Lyme borreliosis: Implications for the fetus. In Rheumatic Disease Clinics of North America; No., 4, Johnson, R.C., Eds.; Saunders: Philadelphia, PA, USA, 1989; Volume 15, pp. 657-677. Available online: http:/ / www.molecularalzheimer.org/files/Gestational_Lyme_Borreliosis_--_/annotated_1989. pdf (accessed on 08 August 2017).

88. Horowitz, R.I. Lyme disease and pregnancy: Implications of chronic infection, PCR testing, and prenatal treatment. In Proceedings of the 16th International Scientific Conference on Lyme Disease \& Other Tick-Borne Disorders, Hartford, CT, USA, 7-8 June 2003; Lyme Disease Foundation: Hartford, CT, USA, 2003.

89. Trevian, G.; Stinco, G.; Cinco, M. Neonatal skin lesions due to a spirochetal infection: A case of congenital Lyme borreliosis. Int. J. Dermatol. 1997, 36, 677-680.

90. Grunwaldt, E.; Barbour, A.G.; Benach, J.L. Simultaneous occurrence of babesiosis and Lyme disease. N. Engl. J. Med. 1983, 308, 1166.

91. Cameron, D.J.; Johnson, L.B.; Maloney, E.L. Evidence assessments and guideline recommendations in Lyme disease: The clinical management of known tick bites, erythema migrans rashes and persistent disease. Expert Rev. Anti-Infect. Ther. 2014, 12, 1103-1135. [CrossRef] 